\title{
Social Perceptions of Forest Ecosystem Services in the Democratic Republic of Congo
}

\author{
Aida Cuni-Sanchez ${ }^{1,2}$ (D) $\cdot$ Gerard Imani $^{3} \cdot$ Franklin Bulonvu $^{4} \cdot$ Rodrigue Batumike $^{5} \cdot$ Grace Baruka $^{6} \cdot$ Neil D. Burgess ${ }^{7,8} \cdot$ \\ Julia A. Klein ${ }^{2} \cdot$ Rob Marchant ${ }^{1}$
}

Published online: 4 December 2019

(C) The Author(s) 2019

\begin{abstract}
The forests of the Albertine Rift are known for their high biodiversity and the important ecosystem services they provide to millions of inhabitants. However, their conservation and the maintenance of ecosystem service delivery is a challenge, particularly in the Democratic Republic of the Congo. Our research investigates how livelihood strategy and ethnicity affects local perceptions of forest ecosystem services. We collected data through 25 focus-group discussions in villages from distinct ethnic groups, including farmers (Tembo, Shi, and Nyindu) and hunter-gatherers (Twa). Twa identify more food-provisioning services and rank bush meat and honey as the most important. They also show stronger place attachment to the forest than the farmers, who value other ecosystem services, but all rank microclimate regulation as the most important. Our findings help assess ecosystem services trade-offs, highlight the important impacts of restricted access to forests resources for Twa, and point to the need for developing alternative livelihood strategies for these communities.
\end{abstract}

Keywords Socio-cultural assessment $\cdot$ Montane forests $\cdot$ Place attachment Forest use $\cdot$ Forest management $\cdot$ Ecosystem services $\cdot$ Farmers $\cdot$ Hunter-gatherers $\cdot$ Albertine Rift $\cdot$ Democratic Republic of the Congo

\section{Introduction}

Ecosystem services (ES) are the ecological characteristics, functions, or processes that directly or indirectly contribute to human wellbeing (Costanza et al. 1997; MEA 2005). The ES approach has undergone significant theoretical and methodological development in the last two decades (see Costanza

Electronic supplementary material The online version of this article (https://doi.org/10.1007/s10745-019-00115-6) contains supplementary material, which is available to authorized users.

Aida Cuni-Sanchez

aidacuni@hotmail.com

1 York Institute for Tropical Ecosystems, Department of Environment and Geography, Wentworth Way, University of York, Heslington, York YO10 5NG, UK

2 Department of Ecosystem Science and Sustainability, Colorado State University, Campus Delivery 1476, Fort Collins, CO 80523, USA

3 Biology Department, Université Officielle de Bukavu, Bukavu, Democratic Republic of Congo

4 Departement de Eaux et Forêts, Institut Superieur d'Agroforesterie et de Gestion de l'Environnement de Kahuzi-Biega (ISAGE-KB), Kalehe, Sud-Kivu, Democratic Republic of Congo et al. 2017), and has become widely used to inform policy makers and land-use managers of the links between ecosystem functions and human wellbeing (Fisher et al. 2009). However, some have argued that the ES concept is overly simplistic and largely inaccurate, neglecting the reality that humans often contribute to the composition, maintenance, and enhancement of ecosystems (e.g., Comberti et al. 2015). Further, for peoples
5 Département de sciences de l'environnement, Université du Cinquantenaire Lwiro, Kabare, Suk-Kivu, Democratic Republic of Congo

International Union for Conservation of Nature, BP 8265, Kin I Kinshasa, Democratic Republic of Congo

Center for Macroecology, Evolution and Climate, University of Copenhagen, Universitetsparken 15 ,

DK-2100 Copenhagen, Denmark

8 UN Environment World Conservation Monitoring Center, (UNEP-WCMC), 219 Huntingdon Road, Cambridge, UK 
whose worldviews encompass kinship between people and nature, such as indigenous communities worldwide, the ES approach is too instrumental, and may even be offensive, as it overlooks at nature's intrinsic values and connections to humanity (see Díaz et al. 2015). The ES concept has also been criticized for having contributed to 'Banking Nature,' rewriting conservation practice and non-human worlds in terms of banking and financial categories (Sullivan 2013).

A recent publication of the Intergovernmental SciencePolicy Platform on Biodiversity and Ecosystem Services (IPBES) (see Díaz et al. 2018) highlighted the ES concept as a predominantly stock-and-flow framing of people-nature relationships that has largely failed to engage a range of perspectives from the social sciences, and that the notion of "nature's contributions to people' (NCP), which recognizes the central and pervasive role that culture plays in defining all links between people and nature, is more useful. Others have criticized the NCP approach, noting that it is neither novel nor an improvement over ES (Braat 2018). In this research we use the more widely accepted concept of ES, highlighting the economic, ecological, and socio-cultural values they provide (de Groot et al. 2002).

Although it is increasingly recognized that assessment of ES demands an integrative approach including ecological, economic and socio-cultural evaluation criteria (Burkhard et al. 2010), most research has taken either an ecological or an economic approach, or a combination of the two (Raymond et al. 2013). However, the importance of including sociocultural evaluation is increasingly acknowledged (Scholte et al. 2015), particularly, as a strategy for sustainable development and effective conservation (Chan et al. 2012; MartínLópez et al. 2012; Kari and Korhonen-Kurki 2013; Cáceres et al. 2015; Kovács et al. 2015). Socio-cultural ES evaluation uses research methods from the social sciences (e.g., interviews), valorizes ES in non-monetary terms (e.g., perceptions), and explicitly makes stakeholders the focal point of the research (Orenstein and Groner 2014). These approaches can complement and increase the value of traditional economic and ecological approaches: (a) valorize cultural services, (b) clarify complex socio-ecological systems, and (c) ensure social relevance and policy-making relevance (see Orenstein and Groner 2014). Moreover, they also ensure that subsequent management interventions are embedded and work within the local socio-cultural context.

Socio-cultural ES evaluation enables identification of differences in perceptions among stakeholder groups (e.g., Iniesta-Arandia et al. 2014). Since willingness to conserve one ES might be at the expense of another, divergent stakeholder priorities can be used to identify possible trade-offs among different ES (Martín-López et al. 2012; Kari and Korhonen-Kurki 2013).

Stakeholders' values of ES vary due to a complex set of factors, including: (i) stakeholder social (e.g., cultural background, social network) and personal (e.g., income, age, gender, education, location of residence) characteristics, but also (ii) interactions among stakeholders and ES associated with use, perception, and knowledge of ES (see Scholte et al. 2015). The type of knowledge stakeholders hold (i.e., experiential or experimental) is also important (Lewan and Söderqvist 2002; Lamarque et al. 2011). For example, in the Ecuadorian Amazon, Mestizo professionals and Shuar farmers identified a similar number of ES, but Mestizos with a better education and socioeconomic situation identified more regulating services (air purification, climate regulation, and soil fertility); while Shuar identified more provisioning services (palms, medicinal plants, wood and wild fruits) (Caballero-Serrano et al. 2017). In southwest Ethiopia men recognized more forest ES than women (Tadesse et al. 2014). In Rwanda, long-term residents identified a greater number of forest ES than newcomers (Dawson and Martin 2015). Degree of place attachment, broadly defined as the bond between people and a specific place (Williams et al. 1992) with two components place identity and place dependence (Raymond et al. 2010) also influences stakeholders' valorization of ES (Lakerveld et al. 2015; Cundill et al. 2017).

Local people dependent on provisioning ES, e.g., residents of a study area whose livelihoods are strongly related to smallscale farming, herding, or forestry (Iniesta-Arandia et al. 2014), comprise an important stakeholder group in ES assessments, although they may have competing priorities regarding ES depending on ethnicity (Allendorf and Yang 2013; Gould et al. 2014; Lakerveld et al. 2015; Cuni-Sanchez et al. 2016) or livelihood strategies (e.g., Carson et al. 2018). For instance, Baka hunter-gatherers identify a greater number of foodprovisioning ES from nearby forests compared with Bantu farmers (Carson et al. 2018).

Socio-cultural preferences (related to ethnicity and/or livelihood strategy) toward plant species have long been studied in the field of wild plant utilization (ethnobotany, ethnomedicine, wild edible fruits and vegetables) (e.g., Assogbadjo et al. 2012; Sop et al. 2012). Determining patterns of plant use with regard to certain provisioning ES (e.g., medicinal resources, wild fruits) can complement ES assessments as they help identify potential alternative livelihood strategies (e.g., honey production) for communities living near protected areas (Cuni-Sanchez et al. 2016).

The mountains of the Albertine Rift in Africa are known for their exceptional biodiversity: about 7500 plant and animal species have been recorded, over 1000 of which are endemic (Plumptre et al. 2003). The forests in particular, provide a wide range of ES from local to international scales, including water, timber and non-timber forest products, hazard prevention, climate modulation, and carbon sequestration, among others (Alweny et al. 2014). Despite the number of protected areas, the conservation of these forests is a challenge, particularly in the Democratic Republic of the Congo (DR Congo), where 
five World Heritage Sites have been placed on the 'In Danger' list for more than 20 years. To date, engagement of local populations in the management of Congolese forests has been limited (Kujirakwinja et al. 2018). In order to design effective forest management interventions that also prevent harm and promote the wellbeing of local populations, it is important to consider local populations' needs and perspectives (Martin et al. 2016). To facilitate the design of such management interventions, we investigated perceptions of forest benefits among different groups of local peoples living near two protected forests in eastern DR Congo, a region that has suffered from several recent armed conflicts and for which available data are very limited. The management plan for the first protected area considered is due to be reviewed as it expires in December 2019; and the second protected area currently has no management plan, although one is being drafted.

Our objectives were: (i) to investigate how local communities identify and prioritize forest ES, and if these differ according to livelihood and ethnic differences; and (ii) to assess if livelihood and ethnic differences affect the selection of most important tree species used for different provisioning ES. Following Carson et al. (2018), we hypothesized that in our study area: (i) Twa hunter-gatherers would identify more forest ES than Bantu farmer groups, (ii) they would place higher value on food products, and (iii) they would recognize more tree species for provisioning services. We also hypothesized that they would have greater place attachment with the forest than Bantu farmer groups.

\section{Methods}

\section{Study Area}

We selected the communities living adjacent to two forested mountains in eastern DR Congo: Mt Kahuzi (3320 m) and the Itombwe Mountains (Mts) (Mt Mohi 3475 m) (Fig. 1). In Mt Kahuzi, annual rainfall ranges between 1500 and $2000 \mathrm{~mm} \mathrm{yr}^{-1}$, and humidity is close to $76 \%$ (Fischer 1996). In the Itombwe Mts annual rainfall ranges between 1200 and $3000 \mathrm{~mm} \mathrm{yr}^{-1}$ (Doumenge 1998). In both areas, important climatic differences can be observed with increasing altitude (colder and wetter), with fog being a common feature at high altitudes. The montane forests in these mountains are floristically similar (see Table A1, Appendix). Both mountains are part of the Albertine Afromontane Biodiversity Hotspot (Myers et al. 2000), and support globally important populations of Grauer's gorilla (Gorilla beringei graueri), eastern chimpanzee (Pan troglodytes schweinfurthii) and forest elephant (Loxodonta africana var. cyclotis) (Plumptre et al. 2009).

Mt Kahuzi montane forest is located within the KahuziBiega National Park (NP). Created as a Zoological and Forest Reserve in 1937, it became a National Park in 1970, when communities living inside (mainly Twa huntergatherers) were evicted without compensation (Barume 2000). The park was extended into the lowlands in 1975 , and more people were evicted (mostly Shi, Tembo, and Rega farmers). In 1981, it became a World Heritage Site, because of the small remaining population of Grauer's gorilla. In 1997, it was listed as a World Heritage Site In Danger as a consequence of armed conflict in the eastern parts of the country. As of 2019, it remains a 'World Heritage Site In Danger' because of illegal mining, bush meat hunting, presence of villages within the park, and presence of armed militia involved in poaching, mining, and charcoal trading, resulting in a lack of security for park rangers (Institut Congolais pour la Conservation de la Nature (ICCN) unpublished report). Access to Mt Kahuzi montane forest is restricted (no hunting or plant product collection allowed). There is barely any forest outside the NP in the eastern part of Mt Kahuzi, where Shi and Twa ethnic groups live.

The recent history of the Itombwe Nature Reserve is quite different to that of Mt Kahuzi. Several surveys during the 1990s highlighted the presence of large mammals (including Grauer's gorilla) and over 500 bird species (Omari et al. 1999). These surveys also found increasing threats and the presence of several armed groups controlling various parts of the mountain. In 2006, the Minister for the Environment declared unilaterally that a reserve would be established in the Itombwe Mts. International and national human rights and conservation NGOs, local communities, and protected area authorities took over 10 years to formalize the boundaries of the now called Itombwe Nature Reserve (Kujirakwinja et al. 2018). Access to the forests in the Itombwe Mts is not restricted, and there are some community forests surrounding this reserve.

Several ethnic groups live around these two montane forests (Fig. 1). Tembo, Twa, and Shi inhabit the region around Mt Kahuzi, while Nyindu and Shi are found in the northern part of the Itombwe Mts. Tembo, Shi, and Nyindu are farmers of Bantu origin, while Twa are 'Pygmy' hunter-gatherers. Here we use livelihood strategy (farmer or hunter-gatherer) to refer to the main activity used to provide food, shelter, and income for a given household, which, in our study area, is related to people's identity and culture. Livelihood strategy not only involves making a living. There is a moral or cultural dimension to livelihood choice as well as a material dimension (Bebbington 2000). Although some households have started to diversity their livelihoods (e.g., some farmers have started rearing goats), people in the study area still consider themselves either farmers or hunter-gatherers (rather than e.g., agro-pastoralist), because livelihood strategy has important socio-cultural connotations.

Twa are the poorest members of the current society: they are landless, barely have access to education, healthcare, microfinance or training opportunities, and they are 
Fig. 1 Study area including Kahuzi-Biega National Park (NP), Itombwe Nature Reserve (NR), highest mountains (Mt Kahuzi and Mt Mohi), main road (dark line) and villages where focus-group discussions were carried out (black dots). Note that five villages were sampled per ethnic group and mountain but some villages were close to each other and appear as one dot in the map (especially for Twa and Shi near Mt Kahuzi). The boundary of Itombwe NR has changed but we were unable to obtain the new delimitation, the one displayed is from the World Database on Protected Areas (WDPA).

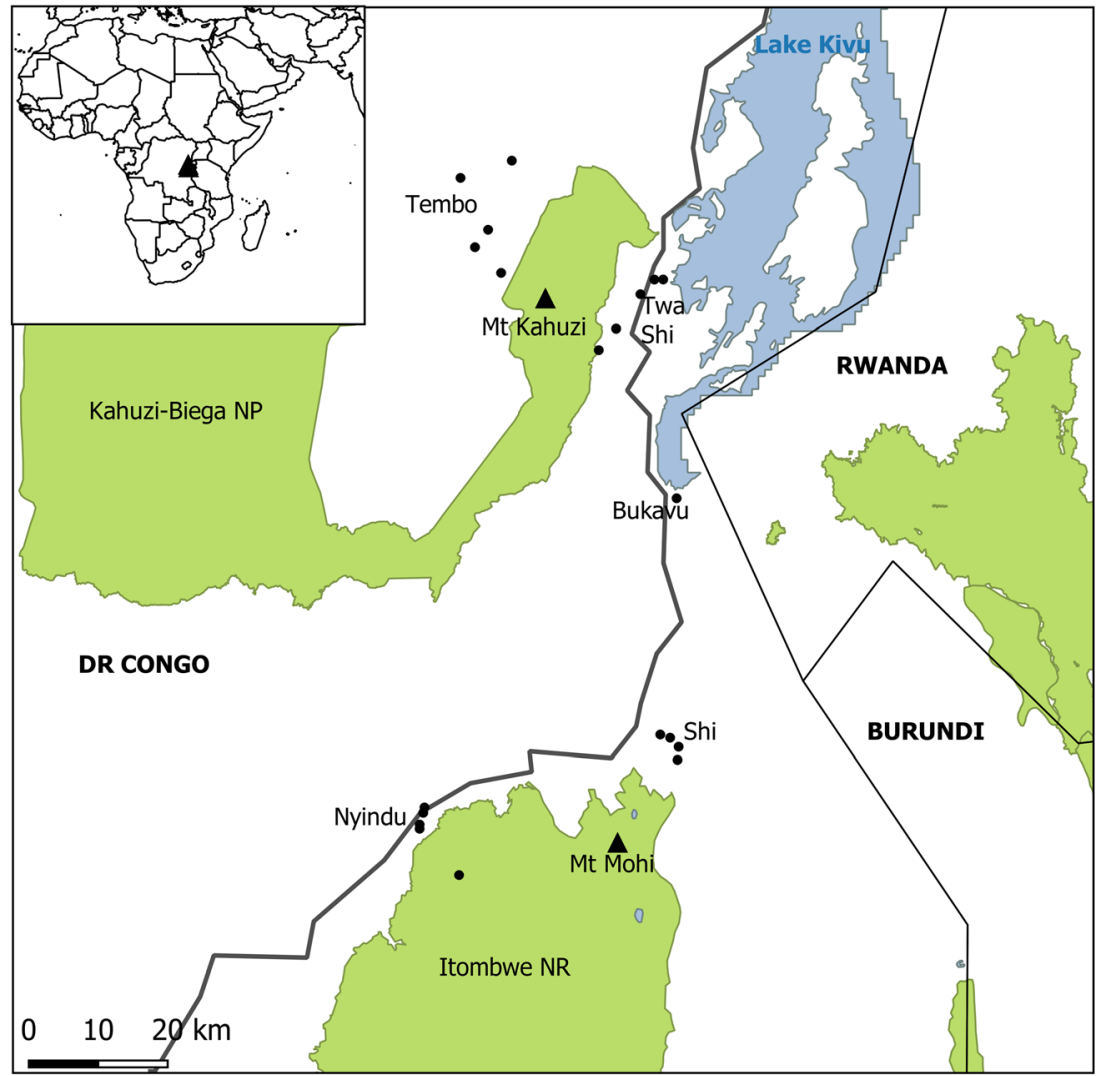

continuously marginalized and abused by ethnic other groups. Following their eviction from their ancestral lands when the Kahuzi-Biega NP was created, they live in mud houses on small parcels of land borrowed from the chiefs' of their neighboring Bantu communities. Without access to enough land to cultivate, and with no skills to find other jobs, most household heads still make a living from hunting or gathering in the forest (despite being illegal), while a few cultivate and commercialize marihuana (also illegal, Batumike R. ongoing survey). ${ }^{1}$ Insecurity (presence of armed groups hiding in the forest) is higher in the areas where Tembo and Nyindu live. Market access is also lower in these areas due to poor road conditions and greater distance to the Bukavu urban center (Fig. 1).

\section{Data Collection}

We held focus-group discussions (FGDs) in 25 permanent villages located around the two montane forest regions (Fig. 1) in November-December 2017. Five villages from each ethnic group were selected from 'safe' regions (for researchers, given the militia in the region) around these mountains. Most of the villages studied were forest-edge villages in

\footnotetext{
${ }_{1}^{1}$ Twa near Virunga National Park also cultivate and commercialize marihuana to make a living (National Geographic 2017).
}

which fields are still cultivated near the forest but houses have been relocated to nearby major roads/towns because of the past insecurity in the area. Each FGD involved 4-8 village elders, including the village chief (as it is a custom in the area). Most participants were male, as this was often the preference of the chief for cultural reasons, but 1-2 female elders participated in villages where few male elders are present (others had been killed during the armed conflicts in the area). In this study area, elder females talk openly in front of males. After we explained the aim of the study to the village chief, he explained it to the elders and some decided to participate on a voluntary basis. There were no differences in the organization of the FGDs among villages. The FGDs were facilitated and translated by a native speaker of the same ethnicity of the FGDs we were working on, except for Nyindu for which Swahili was used, as all participants were fluent in this language.

Participants were first informed that the aim of the study was to better understand the importance of montane forest for local communities. Secondly, informal discussions centered on assessing the importance of the forest by listing the benefits it provides (open question with no limit of the benefits that could be selected). Thirdly, participants were asked to identify the two most important benefits in each village, stating the reasons behind their choices. Participants identified forest benefits using their own terminology; these benefits were subsequently grouped according to the Millennium Ecosystem 
Assessment's classification of ES types and sub-categories (MEA 2005), e.g., 'the forest attracts rains' became microclimate regulation. Fourthly, they were asked how 'attached' they were to the forest in terms of place identity and place attachment, using their own words. Afterwards, they were asked to select the three species they considered the most important for firewood, construction poles, and medicinal resources. Wild fruits were not included as participants had difficulties in identifying more than one tree species used for this purpose (other than Myrianthus arboreous). The FGD facilitator guided the groups to reach consensus; therefore, comments made in a single FGD were considered to be the general opinion of the FGD. Notes were taken rather than a full transcription of the discussion. In Mt Kahuzi, as local communities do not have legal access to the forest, we made it clear that we asked about all benefits from the forest including those to which they no longer have legal access (Appendix B).

Plant species' names mentioned in FGDs were related to scientific names as follows. For common trees (local name in several languages available at the Herbarium of Lwiro, e.g. published in Yumoto et al. 1994 and Shalukoma et al. 2016), the translator described the species and then asked the elders to confirm that it was the species to which they were referring. For the other plant species, a sample was collected and taken to the Herbarium of Lwiro for identification. Species presence in a particular mountain region and their conservation status was also checked with the literature (Doumenge 1998 for Itombwe Mts; Imani et al. 2016 for Mt Kahuzi). Plant nomenclature follows the Plant List (www.theplantlist.org). Six species are reported using only their local name, as their samples were sterile, of poor quality, and could not be identified.

\section{Data Analysis}

Data from all FGDs from one ethnic group and mountain were pooled together: e.g. Shi-K refers to Shi FGDs in the Mt Kahuzi region, and Shi-I refers to Shi FGDs in the Itombwe Mts. Therefore, we had different combinations: (1) same livelihood strategy and location but different ethnicity (Tembo vs Shi-K in Mt Kahuzi, Nyindu vs Shi-I in the Itombwe Mts), (2) different livelihood strategy and ethnicity but same location (Twa vs Tembo and Shi-K), and (3) same livelihood strategy and ethnicity but different location (Shi-I vs Shi-K).

With regard to 'place attachment,' we noted mentions of cultural practices such as certain ceremonies carried out only in the forest; connections between social cohesion and responsibility with the forest; the sense of 'home' in the forest; and the link of the forest to family history, following the categories used by Cundill et al. (2017). The greater the number of these key aspects mentioned, the higher the rating of 'place attachment.'
To compare the similarity between plant species mentioned by participants in the different mountains and of different ethnic groups, we computed the Jaccard similarity coefficient (J), defined as the size of the intersection divided by the size of the union of the sample sets:

$J(A, B)=\frac{A \cap B}{A \cup B}$

where $\mathrm{A}$ and $\mathrm{B}$ are the binary descriptions of species presence/ absence in different groups (in our case, as mentioned by different ethnic groups). A value of 1 indicates complete similarity, while 0 indicates complete dissimilarity. We also calculated the number of times each species was mentioned in a study area and the number of important uses that were listed. The most frequently mentioned species for a given ES was considered the most important while the most important species overall was the species with more uses and mentioned more times.

\section{Results}

\section{Ecosystem Service Identification and Importance}

The total number of ES mentioned by the different ethnic groups ranged between 16 (Shi-I) and 21 (Tembo) (see Table 1). Eleven ES were cited by all ethnic groups: poles, firewood, medicinal resources, bush meat, caterpillars, mushrooms, wild fruits, water, ceremonies, microclimate regulation, and air purification. This suggests that forest access (restriction in Mt Kahuzi) did not affect the identification of ES by ethnic groups. Most of the ES cited by all ethnic groups were also cited by all FGDs in that ethnic group, with very few differences between ethnic groups (Fig. 2). All ethnic groups cited numerous food items from the forest, including bush meat, caterpillars, mushrooms, wild fruits and honey (honey was not cited by Nyindu, Fig. 3).

A number of ES were reported by only one ethnic group, i.e., erosion control (Tembo), shelter during conflict and candles (Nyindu), fodder (Shi-K and Shi-I); and termites, edible leaves, crabs, shelter (home) and identity (Twa) (Table 1). Soil formation (related to increased soil fertility under forested land) and minerals were reported by all ethnic groups except the Twa. Small differences were observed between Shi-K and Shi-I: Shi-K mentioned bamboo and tourism, while Shi-I mentioned baskets, ropes, and tools (Table 1). Aside from provisioning services, participants also mentioned regulating services (e.g., microclimate regulation), supporting services (e.g. soil formation) and cultural services (e.g., ceremonies). With regard to ceremonies, Twa mentioned more ceremonies than the other ethnic groups, including offerings to their ancestors (Table 2).

The two most highly ranked ES varied among ethnic groups, with clear differences between the Twa and the other 
Table 1 Important ecosystem services, number of ecosystem services and all ecosystem services mentioned in the focus-group discussions (FGDs) by ethnic group and location. Values refer to number of FGDs citing an ecosystem service ( $n=5$ for each ethnic group). Shi-K refer to Shi in Mt Kahuzi, while Shi-I refer to Shi in the Itombwe Mts

\begin{tabular}{|c|c|c|c|c|c|c|}
\hline & & \multicolumn{3}{|l|}{ Mt Kahuzi } & \multicolumn{2}{|l|}{ Itombwe Mts } \\
\hline \multicolumn{2}{|l|}{$\begin{array}{l}\text { Most } \\
\text { important ES }\end{array}$} & $\begin{array}{l}\text { Tembo } \\
\text { Micro-climate, air } \\
\text { purification }\end{array}$ & $\begin{array}{l}\text { Twa } \\
\text { Bush meat, } \\
\text { honey }\end{array}$ & $\begin{array}{l}\text { Shi-K } \\
\text { Micro-climate, soil } \\
\text { formation }\end{array}$ & $\begin{array}{l}\text { Shi-I } \\
\text { Micro-climate, soil } \\
\text { formation }\end{array}$ & $\begin{array}{l}\text { Nyindu } \\
\text { Micro-climate, air } \\
\text { purification }\end{array}$ \\
\hline \multicolumn{2}{|c|}{ No. ES mentioned } & 21 & 19 & 17 & 16 & 19 \\
\hline \multirow[t]{4}{*}{ Regulating } & $\begin{array}{l}\text { Micro-climate } \\
\text { regulation }\end{array}$ & 5 & 3 & 5 & 5 & 3 \\
\hline & Air purification & 5 & 2 & 5 & 4 & 5 \\
\hline & Erosion control & 2 & & & & \\
\hline & Water purification & 2 & & & & 2 \\
\hline Supporting & Soil formation & 5 & & 5 & 5 & 4 \\
\hline \multirow[t]{20}{*}{ Provisioning } & Water & 2 & 3 & 2 & 1 & 2 \\
\hline & Poles & 5 & 5 & 5 & 5 & 5 \\
\hline & Bamboo & 2 & & 3 & & \\
\hline & $\begin{array}{l}\text { Timber for } \\
\text { furniture }\end{array}$ & 2 & & & & 2 \\
\hline & Firewood & 5 & 5 & 5 & 5 & 5 \\
\hline & Medicine resources & 5 & 5 & 5 & 5 & 5 \\
\hline & $\begin{array}{l}\text { Baskets, ropes, } \\
\text { tools. }\end{array}$ & 5 & 5 & & 5 & 5 \\
\hline & Candles $^{\mathrm{a}}$ & & & & & 2 \\
\hline & Bush meat & 5 & 4 & 4 & 5 & 5 \\
\hline & Caterpillars & 5 & 5 & 5 & 5 & 5 \\
\hline & Mushrooms & 5 & 5 & 5 & 5 & 5 \\
\hline & Wild fruits & 5 & 5 & 3 & 5 & 5 \\
\hline & Honey & 3 & 5 & 5 & 2 & \\
\hline & Termites & & 1 & & & \\
\hline & Edible leaves & & 5 & & & \\
\hline & Crabs & & 3 & & & \\
\hline & Small fish & 2 & 2 & & & 2 \\
\hline & Fodder & & & 3 & 5 & \\
\hline & Minerals & 2 & & 3 & 1 & 1 \\
\hline & Shelter during confl & & & & & 2 \\
\hline \multirow[t]{3}{*}{ Cultural } & Tourism & 1 & & 1 & & \\
\hline & $\begin{array}{l}\text { Identity } \\
\text { Shelter (home) }\end{array}$ & & $\begin{array}{l}5 \\
5\end{array}$ & & & \\
\hline & Ceremonies & 5 & 5 & 3 & 3 & 5 \\
\hline
\end{tabular}

${ }^{a}$ refers to the gum of Canarium schweinfurthii Engl. used as 'local candle'

groups. Twa mentioned bush meat and honey (two provisioning ES), and the other ethnic groups mentioned microclimate regulation, soil formation, and air purification (regulating or supporting ES, see Table 1).

\section{Place Attachment}

Twa showed greater place attachment than the other ethnic groups, as they mentioned not only ceremonies, but also the importance of forests for social cohesion and responsibility, the sense of 'home' for the forest, the link of the forest to family history (ancestors), the importance of the forest for food security, health, physical security, livelihood strategy, and cultural identity (Table 2). For example, they noted that: 'the forest is like a mother to us, it provides everything for us, and we have the duty of taking care of her' (Table 3 ). This is similar to the 'Mother Earth' perception of indigenous people elsewhere (see Díaz et al. 2015). With regard to social cohesion, Twa explained: 'Now it is difficult to be in touch and be on time for important things. You hear about a relative dying 
Fig. 2 Number of times an ecosystem service was mentioned by each ethnic group and location. Five focus group discussions were organised in each ethnic group and location. Shi-K refer to Shi in Mt Kahuzi, while Shi-I refer to Shi in the Itombwe Mts

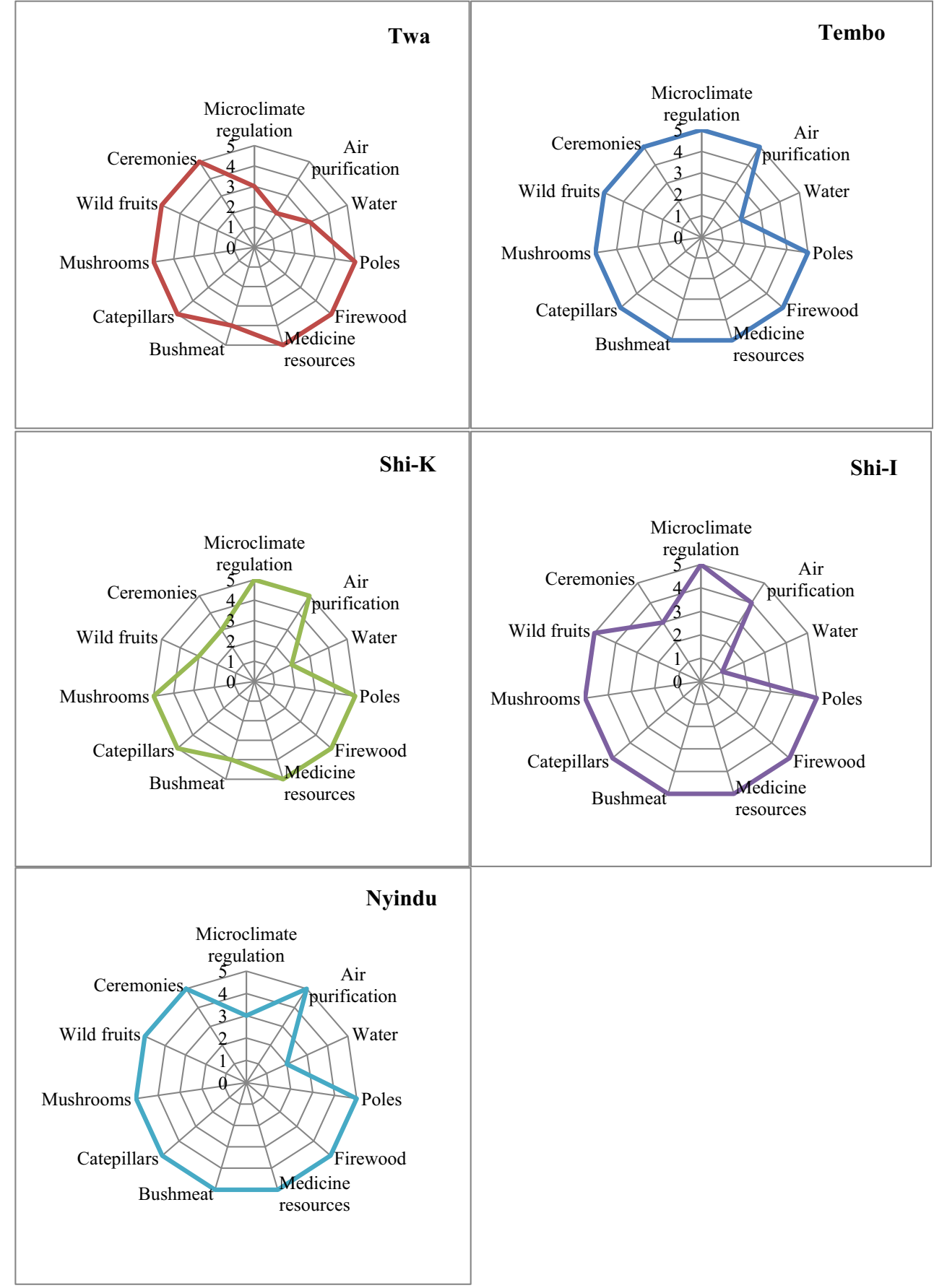

after he has already been buried. We are not connected as we used to be.'

\section{Preferred Plant Species for Medicine, Construction, and Firewood}

Overall, 22 species in these categories were mentioned by Tembo, 12 by Twa, 21 by Shi-K, 28 by Nyindu, and 25 by Shi-I (Table 4). The different Jaccard indexes of similarity $(\mathrm{J})$ were quite low $(<0.25)$ highlighting the differences among preferred species between groups studied. J was 0.24 for Shi-K/Twa, 0.16 Shi-K/Tembo, 0.13 for Shi-K/Shi-I, 0.13 for Nyindu/ Shi-I and lower for the other combinations. Several species were mentioned only by one ethnic group or only in one study site (Table A2, Appendix).

In Mt Kahuzi, the most preferred species for medicine (Carapa grandiflora), construction (Strombosia scheffleri) and firewood (Macaranga kilimandscharica) were the same for Shi-K and Twa. Tembo also mentioned Strombosia 
Fig. 3 Food forest ecosystem services, as mentioned by each ethnic group. Five focus group discussions were organised in each ethnic group and location

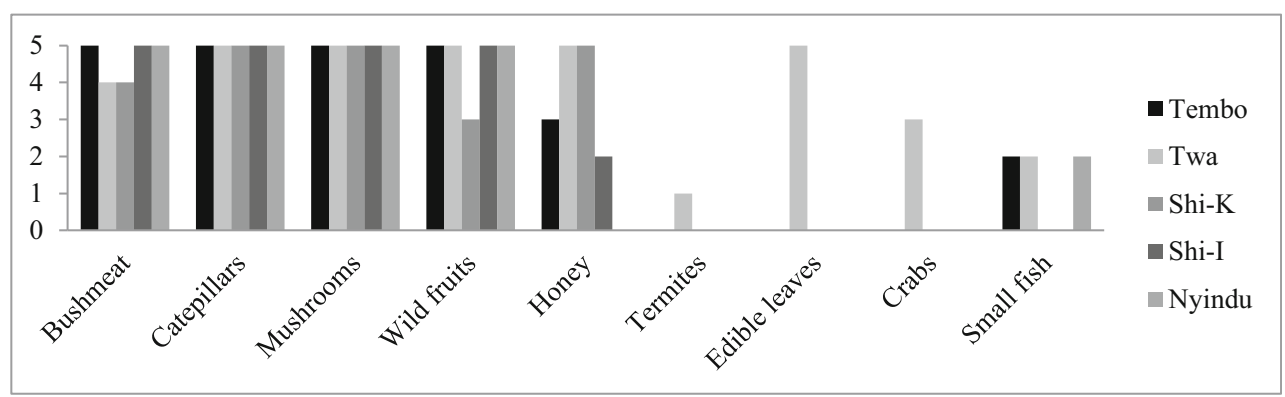

scheffleri as preferred species for construction. In the Itombwe Mts, preferred species for medicine, construction and firewood differed between Shi-I and Nyindu. Overall, the most important species (mentioned by more FGDs and with more uses) was Syzygium guineense for Shi-K and Shi-I, Carapa grandiflora for Twa and Tembo, and Ocotea usambarensis for Nyindu (Table 4).

Most species mentioned in FGDs are abundant trees in the forests of the study sites (Table A2, Appendix). Also, most species mentioned by participants in the Itombwe Mts but not mentioned in Mt Kahuzi are also found there, although in some cases they are less abundant. Although there is less available information on the trees of the Itombwe Mts, it seems that that most species mentioned in Mt Kahuzi but not mentioned in the Itombwe Mts are also found there.

\section{Discussion}

\section{Ecosystem Service Identification and Importance}

Our results indicate that livelihood strategy and ethnicity affect identification and ranking of ES, but that the effects of location are limited. We had hypothesized that (i) Twa huntergatherers would identify more forest ES than Bantu farmer groups and (ii) they would place higher value on food products. Indeed, Twa placed higher value on food products, and identified more forest ES than Shi farmers (but not more than Nyindu or Tembo farmers). Twa ranked bush meat and honey (their staple food) as the two most important ES while all farmer ethnic groups mentioned microclimate regulation (rains are important for farming), reflecting their livelihood strategies: hunter-gathering and farming, respectively.

Table 2 Types of ceremonies carried out in the forest by ethnic group, and comments made during discussions with regard to place attachment. Shi-K refer to Shi in Mt Kahuzi, while Shi-I refer to Shi in the Itombwe Mts

\begin{tabular}{|c|c|c|c|c|c|}
\hline & Twa & Tembo & Nyindu & Shi-K & Shi-I \\
\hline \multicolumn{6}{|l|}{ Ceremonies } \\
\hline Burial/coronation of mohami (local chief-king) & & $\mathrm{x}$ & $\mathrm{x}$ & $\mathrm{x}$ & $\mathrm{x}$ \\
\hline Burial of court men & $\mathrm{x}$ & & & & \\
\hline Initiation young boys & $\mathrm{x}$ & $\mathrm{x}$ & $\mathrm{x}$ & & \\
\hline Initiation young girls & $\mathrm{x}$ & & & & \\
\hline Offerings to ancestors & $\mathrm{x}$ & & & & \\
\hline Other ceremonies (e.g. for the sick) & $\mathrm{x}$ & & & & \\
\hline \multicolumn{6}{|l|}{ Place attachment } \\
\hline \multicolumn{6}{|l|}{ (1) Place identity } \\
\hline Ceremonies & $\mathrm{x}$ & $\mathrm{x}$ & $\mathrm{x}$ & $\mathrm{x}$ & $\mathrm{x}$ \\
\hline Social cohesion and responsibility & $\mathrm{x}$ & & & & \\
\hline Sense of 'home' & $\mathrm{x}$ & & & & \\
\hline Link land to family history (e.g. ancestors) & $\mathrm{x}$ & & & & \\
\hline Link land to future generations & $\mathrm{x}$ & & & & \\
\hline \multicolumn{6}{|l|}{ (2) Place dependence } \\
\hline Food security & $\mathrm{x}$ & & & & \\
\hline Health & $\mathrm{x}$ & & & & \\
\hline Physical security & $\mathrm{x}$ & & & & \\
\hline Livelihood strategy & $\mathrm{x}$ & & & & \\
\hline
\end{tabular}


Table 3 Key aspects of place attachment identified during discussions with Twa, and examples of comments made

\begin{tabular}{|c|c|}
\hline Themes & Examples \\
\hline Food security & $\begin{array}{l}\text { 'Here [outside the forest] we are weak and hungry, we do not have the food we are used to: bush meat and honey. That is the food that } \\
\text { makes you strong'. }\end{array}$ \\
\hline \multirow[t]{3}{*}{ Health } & 'When we were in the forest we ate better food so we had fewer diseases'. \\
\hline & 'Before we could use lots of medicinal plants to help us when we were sick'. \\
\hline & 'In the villages there are diseases which do not exist in the forest, we were healthier before'. \\
\hline \multirow[t]{2}{*}{ Physical security } & $\begin{array}{l}\text { 'In the forest we felt secure. Here we are in the land of the Shi who brutalise and marginalise us all the time. They rape our women } \\
\text { and even try to poison us'. }\end{array}$ \\
\hline & $\begin{array}{l}\text { 'Shi think that we are 'primitive and wild' and they marginalise us. To us, they [Shi] are the primitive and wild, as they are bad to } \\
\text { each other, they fight among themselves and can even kill each other, something a Twa would never do. To us, they are the } \\
\text { uncivilised ones'. }\end{array}$ \\
\hline \multirow[t]{2}{*}{ Social cohesion } & $\begin{array}{l}\text { 'Since we have been removed from the forest, families have been separated. We used to walk to see relatives, but this is now very } \\
\text { dangerous, as if caught you can be arrested by park rangers, or brutalised by militia men'. }\end{array}$ \\
\hline & $\begin{array}{l}\text { 'Now it is difficult to be in touch and be on time for important things. You hear about a relative dying, after he has already been } \\
\text { buried. We are not connected as we used to be'. }\end{array}$ \\
\hline \multirow[t]{2}{*}{$\begin{array}{l}\text { Link with } \\
\text { ancestors }\end{array}$} & $\begin{array}{l}\text { 'We used to do offerings to our ancestors, who live in the forest. They only want honey and bush meat. Now we cannot do that. We } \\
\text { only pray to them to forgive us and to help us go back to the forest so we can do the right offerings again'. }\end{array}$ \\
\hline & $\begin{array}{l}\text { 'If the offerings to our ancestors are not carried out, evil spirits come and make us sick, or we find nothing to eat, or something bad } \\
\text { happens to us (e.g. a forest guard arrests you'). }\end{array}$ \\
\hline \multirow[t]{3}{*}{ Cultural identity } & 'The forest is important to my people, to who we are as a people. Without the forest, we do not exist'. \\
\hline & $\begin{array}{l}\text { 'They removed us from the forest, to kill our culture and to kill us. Removing us from the forest was the first step to make us disappear } \\
\text { from Earth'. }\end{array}$ \\
\hline & 'Help us go home [to the forest]'. \\
\hline \multirow[t]{2}{*}{$\begin{array}{l}\text { Social } \\
\text { responsibility }\end{array}$} & $\begin{array}{l}\text { 'The forest is like a mother to us, it provides everything for us, and we have the duty of taking care of her. But now we live outside and } \\
\text { cannot do that. It is so sad to see how the Shi are mining in the forest and killing the forest. A Twa would never do that'. }\end{array}$ \\
\hline & 'We would never destroy the forest because it is our home. The others [tribes] are the ones destroying our forest, our home'. \\
\hline
\end{tabular}

Importantly, with restricted access to the Mt Kahuzi forest, the Twa have lost access to their most important ES (their staple foods), while farmers still have access to their most important ES (the rains) (see below). Twa also (i) mentioned more food items as ES, and (ii) did not mention some ES such as soil formation and minerals (mentioned by farmers), also reflecting their livelihood strategy of hunter-gathering. Twa are known to gather numerous food items from the forest, including edible ferns (see Mokoso et al. 2012). In southeastern Cameroon, Baka Pygmies also reported that they rely

Table 4 The most preferred species and the total number of species (spp.) reported for different provisioning ecosystem services, and the most important species overall with regard to ethnicity and location. Shi-K refer to Shi in Mt Kahuzi, while Shi-I refer to Shi in the Itombwe Mts

\begin{tabular}{|c|c|c|c|c|}
\hline & Medicine & Construction & Firewood & Overall \\
\hline \multirow[t]{2}{*}{ Tembo } & Pleiocarpa pycnantha & $\begin{array}{l}\text { Strombosia scheffleri, Milicia } \\
\quad \text { excelsa }\end{array}$ & Grewia mildbraedii & $\begin{array}{l}\text { Carapa grandiflora, Pleiocarpa } \\
\text { pycnantha }\end{array}$ \\
\hline & 8 spp. & $11 \mathrm{spp}$. & 8 spp. & 22 spp. \\
\hline \multirow[t]{2}{*}{ Twa } & $\begin{array}{l}\text { Carapa grandiflora, Pleiocarpa } \\
\text { pycnantha }\end{array}$ & Strombosia scheffleri & Macaranga kilimandscharica & Carapa grandiflora \\
\hline & $5 \mathrm{spp}$ & 8 spp. & $6 \mathrm{spp}$ & 12 spp. \\
\hline \multirow[t]{2}{*}{ Shi-K } & $\begin{array}{l}\text { Carapa grandiflora, Syzygium } \\
\text { guineense }\end{array}$ & Strombosia scheffleri & Macaranga kilimandscharica & Syzygium guineense \\
\hline & 9spp. & 9 spp. & $6 \mathrm{spp}$ & $21 \mathrm{spp}$. \\
\hline \multirow[t]{2}{*}{ Shi-I } & Syzygium guineense & Simphonia globulifera & $\begin{array}{l}\text { Syzygium guineense, } S \text {. } \\
\text { cordatum }\end{array}$ & Syzygium guineense \\
\hline & 13 spp. & 11 spp. & 9 spp. & 25 spp. \\
\hline \multirow[t]{2}{*}{ Nyindu } & $\begin{array}{l}\text { Ocotea usambarensis, Prunus } \\
\text { africana }\end{array}$ & $\begin{array}{l}\text { Euclea racemosa subsp. } \\
\text { schimperi }\end{array}$ & $\begin{array}{l}\text { Uapaca guineensis, Treculia } \\
\text { africana }\end{array}$ & Ocotea usambarensis \\
\hline & 11 spp. & 11 spp. & 10 spp. & $28 \mathrm{spp}$. \\
\hline
\end{tabular}


on more food products from the forest than Bantu farmers, and highlighted the importance of the forest for their food security (Carson et al. 2018).

Microclimate regulation is also related to farmers' food security, as farmers need 'good rains and fertile soils to survive' (participant comment during FGDs). Hartter and Goldman (2011) report that farmers in Kibale National Park in Uganda also mentioned improved local rainfall and air quality as important ES from the nearby forest. Similar results have been found in Rwanda, northern Kenya, Ethiopia and Madagascar (Dawson and Martin 2015; Cuni-Sanchez et al. 2016; Byg et al. 2017; Dave et al. 2017; but not in other forests, cf. Paudyal et al. 2018 for Nepal and CaballeroSerrano et al. 2017 for the Ecuadorian Amazon).

While livelihood strategy strongly affected the ranking of the two most important ES, ethnicity affected the identification of ES. For example, across the farmer groups, Nyindu and Tembo mentioned water purification and small fish as food source but did not mention the provision of fodder, while Shi$\mathrm{K}$ and Shi-I did the reverse. Shi are known to place high cultural value on cattle (wealthier Shi own cattle). Location had little effect on ES identification, mainly related to the presence or absence of a given ES in at study site (e.g., bamboo for construction and tourism is only be found in $\mathrm{Mt}$ Kahuzi). Remarkably, forest access (restriction in Mt Kahuzi) did not affect the identification and ranking of ES: Shi in both mountains had similar responses (except for bamboo and tourism). We specifically asked about all forest benefits, as we were aware that many people still access the forest 'illegally' for different reasons.

Contrary to our expectations, bush meat, caterpillars, mushrooms, and wild fruits were listed by all ethnic groups, not only the Twa as we had hypothesized, suggesting that dependency on forest food products is (or has been) high for all groups. This dependency is possibly related to (i) past civil unrest, which caused crop theft or failures, and (ii) cultural preferences (e.g., for bush meat over domestic meat). Bush meat is a significant source of animal protein in all Central African countries and is important for food security in the region (Fa et al. 2003), and it is often the only source of iron (Golden et al. 2011) and fat (Siren and Machoa 2008). A recent study from Kisangani (north-west of Mt Kahuzi) showed that both poor and rich urban households consume bush meat for a variety of reasons, including its cheap cost and taste preferences (van Vliet et al. 2015).

All ethnic groups cited medicinal resources as a key forest ES. Access to western medicine across the study area is very limited with a lack of dispensing facilities, and prohibitively high costs (participants' comments during FGDs). ${ }^{2}$ Apart from lack of availability and its high cost, the Twa mentioned

\footnotetext{
${ }^{2}$ Even malaria treatments, which are subsidized in some countries (e.g., Kenya, see Delbanco et al. 2017), are not subsidized in DR Congo.
}

that they prefer using medicinal plants because they believe western medicine to be ineffective: 'we don't use western drugs even when they give them for free, because they do not work' (participants' comments during FGDs).

All ethnic groups mentioned the use of the forest for ceremonies, (see also Mutoko et al. 2015; Cuni-Sanchez et al. 2016 (Kenya); Ward et al. 2018 (Madagascar)) although the Twa cited more ceremonies than the other groups. Importantly, most assessments of ES in other regions of the DR Congo do not addressed cultural ES, and those that do focus only on tourism opportunities (e.g., Kasangaki et al. 2012; Willemen et al. 2013). Nevertheless, cultural values of forests are frequently considered more important for sustainable forest conservation than many provisioning services especially populations whose cultural identity is intimately linked to forests (Farber et al. 2002).

Most ES mentioned in this study have been noted in other studies on forests in Africa (e.g. Hartter and Goldman 2011; Byg et al. 2017; Dave et al. 2017; Guerbois and Fritz 2017; Ward et al. 2018), with the exception of minerals, shelter during conflict, and shelter (home). Minerals were identified as an important provisioning service in only Nyungwe NP in Rwanda, where gold is extracted in artisanal mines (Dawson and Martin 2015). In our study area, minerals refer to the income provided by artisanal mining of coltan (columbite and tantalite), cassiterite (tin ore), gold, and wolframite (tungsten) which are abundant in parts of Mt Kahuzi and the Itombwe Mts and provide local income from artisanal mines (Spira et al. 2017). The Twa did not mention minerals as an ES as their traditional beliefs forbid them from extracting mineral resources (Table 3). During civil unrest and conflicts the forest provides concealment for affected populations. Although this ES can be very important in areas afflicted by conflict (e.g., northern Kenya, Cuni-Sanchez et al. 2016), in our study it was mentioned in only two FGDs. Participants reported that during the civil war (1996-early 2000s), local populations hid in the forest from the government troops. However, more recently, armed rebel groups hide in the forests and it is safer for local people to live near major roads and towns. Shelter (home) refers to the fact that the Twa regard the forest as their home (see below). We highlight that the approach used for ES assessment can affect the results obtained. As previously shown by CuniSanchez et al. (2016), 'shelter during conflict' is not considered in current mainstream ES assessments (e.g., Costanza et al. 2017; Díaz et al. 2018). The identification of this ES by local communities in our study was made possible by our methodology (open-ended questions) allowing participants to note this often missed, but very important, forest function. As highlighted by Milcu et al. (2013), many ES assessments identify the services easiest to valorize with the established methods rather than identifying services truly valorized by a given community. 


\section{Preferred Tree Species}

We hypothesized that Twa would recognize more tree species for provisioning services than farmers' groups, which was not the case. Ethnicity and location proved to have greater effects on preferred tree species than livelihood strategy (see also Assogbadjo et al. 2012; Cuni-Sanchez et al. 2016). As each ethnic group mentioned numerous trees not mentioned by other ethnic groups, we found an extremely low $\mathrm{J}$ index between groups (cf. Cuni-Sanchez et al. 2016). Greater plant diversity offers more alternatives, which might explain the low $\mathrm{J}$ index between ethnic groups we observed. Location also affected preferred tree species, as people prefer using trees that are abundant in their area. For example, Carapa grandiflora, Syzygium guineense and Strombosia scheffleri are abundant between 1500 and $2400 \mathrm{~m}$ in Mt Kahuzi (Imani et al. 2016) while Prunus africana and Ocotea usambarensis are abundant in the northern part of the Itombwe Mts (Nangalire et al. 2017).

In Mt Kahuzi, some important species for medicinal uses, firewood, and construction were mentioned by two ethnic groups, as did previous studies in the region (Shalukoma et al. 2016; Mokoso et al. 2015). Surprisingly, Shirakiopsis elliptica, reported as a treatment for coughs and small wounds, and Tetracera potatoria, used to treat sexual health complications in males who have extramarital relationships (pers. Obs. 2017) were not mentioned in these previous studies focused on traditional healers in the region, possibly, because these aliments do not require visiting a traditional healer. .

\section{Place Attachment and Perceptions of 'Mother Earth'}

All ethnic groups studied showed a sense of place attachment to the forest, both in terms of place identity and place dependency. However, as we hypothesized, the Twa showed a greater place attachment with the forest, noting that 'the forest is important to my people, to who we are as a people; without the forest, we do not exist.' Berrang-Ford et al. (2012) report that Twa from Bwindi Impenetrable NP in Uganda made similar statements, e.g., 'the forest is our life,' and Gillison (1980) and Durand (2005) report analogous comments made by other indigenous forest peoples in Mexico and Papua New Guinea, respectively. Hunting, fishing, and gathering are often a critical part of autonomy for indigenous groups (Russell et al. 2013). For the Twa, the forest is also key for their food security, health, physical security; they called it 'home' and also referred to the forest as a mother to them who they had the duty to take care for (see also Díaz et al. 2015 and references therein). None of the other ethnic groups, including the Nyindu, described the forest in these terms. It could also be argued that the Twa relate to Wilson's 'biophilia hypothesis' that argues humans have innate connection to nature (Wilson 1984).
One interesting finding is that the responses of Nyindu were not similar to those of the Twa. Although Nyindu are not Pygmies, some consider them as 'Bambuti' or 'forest people' and as closely related to the Twa (which has implications for forest access and land rights as 'peuple autochthone' see Gauthier and Pravettoni 2017). However, others have highlighted that they are savanna people, and more closely related to the Shi (Doumenge 1998). Although clarifying the status of Nyindu is beyond the scope of our study, our findings indicate that their current forest ES valorization and sense of place attachment to the forest is not similar to that of the Twa.

\section{Conclusions}

Our study shows how livelihood strategy and ethnicity affect ES identification and prioritization, and abundance of local flora influence the ranking of important plant species. These findings should be considered when designing interventions for forest conservation and sustainable development.

Bottom-up approaches, such as we used in this study, allow assessment of the presence and extent of trade-offs in ES, which occur when the provision of one ES is reduced as a consequence of increased use of another, or when one stakeholder group captures more of an ES at the expense of others (Rodriguez et al. 2006). In our study area, we found no apparent trade-offs in the use of priority ES among ethnic groups: even if the hunter-gatherer Twa used their preferred ES (bush meat and honey, provisioning ES), farmers could still benefit from their preferred ES (microclimate regulation, regulating ES). People's willingness to use their preferred ES is not always at the expense of other groups, contrary to findings from other sites (e.g., Martín-López et al. 2012). Taking into account why, to what extent, and what trade-offs exist is of key importance to achieve situations were better environmental management also provides better outcomes for different groups of people (Howe et al. 2014).

Our findings also illustrate the impacts of forest conservation strategies (restricted access to Kahuzi-Biega NP) and explain existing resentment among the Twa, who do not perceive the forest in the same way as the other ethnic groups - primarily as a source of ES. Rather, the Twa, who show a strong place attachment with the forest, perceive it as their home and describe it as their mother to whom they owe a duty of care (see also Dawson and Martin 2015; Martin et al. 2015). The exclusion of the Twa from forests and their consequent denial of access to forest products and locations for important sociocultural activities has attracted criticism from human rights groups as forced cultural assimilation (Barume 2000; Beswick 2011), and from scientists who call for greater justice in design of conservation strategies to minimize adverse social impacts (Martin et al. 2015). Forest conservation efforts have contributed to numerous injustices for the Twa, including the 
loss of essential freedoms for self-determination and current difficulties with meeting basic requirements for good physical health and access to livelihood opportunities (Martin et al. 2016). Indeed, some Twa reported feeling they are heading towards extinction (see Table 3). Park managers of KahuziBiega NP have focused on providing Twa with livelihood choices outside the forest (e.g., a goat rearing program), but they have not considered the possibility of determining an agreed level of usage of park products (Steinhauser-Burkart et al. 1995; Pers. Obs. 2017); nor have they addressed the existential identification the Twa feel to the forest. Contrary to what some authors have suggested (e.g.; Barume 2000; Bikaba 2010), we show that the Twa still have extensive knowledge of useful plants in the forest and they still regularly use them. As highlighted by Bitariho (2013) for Bwindi Impenetrable NP, the Twa have different interests and skills in forest use compared with ethnic farmers and therefore should not be grouped with agriculturalists when designing management approaches to conservation of forest resources. Within the context of Sustainable Development Goal 10 (to reduce inequalities), forest conservation should address the needs of disadvantaged and marginalized populations, such as the Twa. As Carson et al. (2018) note for the Baka hunter-gatherers of south-eastern Cameroon, better forest management will require recognizing past injustices and creating equitable benefits to reduce further harm to hunter-gatherer indigenous culture, livelihoods, and ecological knowledge. ${ }^{3}$

Our bottom-up approach also points to livelihood strategies that could promote forest conservation. For example, local peoples could be involved in sustainably harvesting and trading mushrooms, caterpillars, and certain medicinal plants, which they all use and valorize, and which are high in demand in Bukavu market (Pers. Obs. 2017). Participants identified Uapaca guineensis, an important tree for firewood, as 'good for dark tasty caterpillars, which are becoming difficult to find.' A project to plant Uapaca guineensis in degraded parts of the forest could provide a future income source for local populations through collection and trade of these caterpillars. Similar strategies have been suggested for the Baka huntergatherers in south-east Cameroon (e.g., insect harvesting, Tata Ngome et al. 2017; honey harvesting from the wild, Carson et al. 2018).

Our research also provides a new case study of an indigenous population with a world view that supports the position of the IPBES that not all knowledge systems are similar, and that 'Mother Earth' approaches should be integrated in ES assessments (see Díaz et al. 2015). Surprisingly, to our knowledge few studies have addressed the forest ES views of the

\footnotetext{
${ }^{3}$ The caterpillar Bunaeopsis aurantiaca, naturally hosted by Uapaca guineensis, is highly nutritious (433 kcal/100 g, Muvundja et al. 2013).
}

Twa or other Pygmy groups (but see Rickenbach et al. 2017 and Carson et al. 2018 for Baka). The term Pygmies, which derives from the ancient Greek and refers to their short stature, is often used to describe a number of ethnic groups in Africa (e.g., Aka, Baka, Bezan, Efe, Twa, Mbuti, etc.), who in fact speak different languages and have different cultural and morphological characteristics, and live in diverse ecological areas (Verdu 2016). At one time these populations were estimated to number 350,000 people, but recent research has shown that their numbers are closer to 1 million (Olivero et al. 2016). Further research on these populations of mostly huntergatherers is necessary to gain a greater understanding of their local ecological knowledge (LEK) and how this is integrated into their socio-cultural interactions with their environment.

Although the populations we studied are dependent on provisioning ES, all farmers groups ranked microclimate regulation as the most important forest ES. This was a rather unexpected finding that emphasizes the importance of climate to forest-dependent communities. As highlighted by the IPBES (Díaz et al. 2015), indigenous peoples and local communities possess detailed knowledge on their ecosystems and their functioning (e.g., montane forests attract mist and rain and significantly contribute to local climate conditions, Bruijnzeel et al. 2011); they are important contributors to the governance of biodiversity from local to global levels.

Finally, we note that even in socio-cultural approaches to ES, most studies have focused on cultural ES including different forms of tourism and intellectual ES (e.g., Cumming and Maciejewski 2017; Smit et al. 2017; Smith et al. 2017) rather than links between cultural practices and identity formation (but see Cundill et al. 2017). Future research should document the multi-dimensional ways in which people value nature and the implications of their knowledge for the design of strategies that enhance conservation goals and livelihoods; this is critical, especially in Africa, where there has been relatively little research on ES (Costanza et al. 2017). This is urgently needed to help determine informed and effective management actions that can support biodiversity, livelihoods, and attainment of broader development and conservation goals.

Acknowledgements We are deeply grateful to our study participants, who graciously shared their time, energy, and stories. We thank our field assistants and facilitators, especially M. Bisimwa for making this research possible and G. I. Kaboyi at the Herbarium of Lwiro for helping with plant identification.

Funding Information This study was funded by Marie SkłodowskaCurie Actions Global Fellowships, Number 743569.

\section{Compliance with Ethical Standards}

Conflict of Interest The authors declare that they have no conflict of interest. 
Open Access This article is distributed under the terms of the Creative Commons Attribution 4.0 International License (http:// creativecommons.org/licenses/by/4.0/), which permits unrestricted use, distribution, and reproduction in any medium, provided you give appropriate credit to the original author(s) and the source, provide a link to the Creative Commons license, and indicate if changes were made.

\section{References}

Alweny, S., Nsengiyumva, P., and Gatarabirwa, W. (2014). African Mountains Status Report. Africa Sustainable Mountain Development Technical Report No. 1, Kampala, Uganda: ARCOS. Available at: http://www.mountainpartnership.org/. Accessed Mar 2019

Allendorf, T. D., and Yang, J. (2013). The role of ecosystem services in park-people relationships: The case of Gaoligongshan nature reserve in Southwest China. Biological Conservation 167: 187193.

Assogbadjo, A. E., Glèlè Kakaï, R., Vodouhê, F. G., Djagoun, C. A. M. S., Codjia, J. T. C., and Sinsin, B. (2012). Biodiversity and socioeconomic factors supporting farmers' choice of wild edible trees in the agroforestry systems of Benin (West Africa). Forest Policy and Economics 14: 41-49.

Barume, A.K. (2000). Heading towards extinction? Indigenous rights in Africa: the case of the Twa of the Kahuzi-Biega National Park, Democratic Republic of Congo. International Work Group for Indigenous Affairs (IWGIA) Document No. 101, Copenhagen, Denmark. 142pp.

Bebbington, A. (2000). Reencountering development: Livelihood transitions and place transformations in the Andes. Annals of the Association of American Geographers 90: 495-520.

Berrang-Ford, L., Dingle, K., Ford, J. D., Lee, C., Lwasa, S., Namanya, D. B., Henderson, J., Llanos, A., Carcamo, C., and Edge, V. (2012). Vulnerability of indigenous health to climate change: A case study of Uganda's Batwa pygmies. Social Science Medicine 75: $1067 \mathrm{e} 1077$.

Beswick, D. (2011). Democracy, identity and the politics of exclusion in post-genocide Rwanda: The case of the Batwa. Democratization 18: 490-511.

Bikaba, D. (2010). Indigenous people and the Kahuzi-Biega National Park in the Democratic Republic of the Congo. In Painemilla, K. W., Rylands, A. B., Woofter, A., and Hughes, C. (eds.), Indigenous peoples and conservation: From rights to resource management, Conservation International, Washington, DC, pp. 49-59.

Bitariho, R. (2013). Socio-economic and ecological implications of local people's use of Bwindi Forest in south western Uganda. MSc thesis, Makerere University, Kampala. Uganda.

Bruijnzeel, L. A., Mulligan, M., and Scatena, F. N. (2011). Hydrometeorology of tropical montane cloud forests: Emerging patterns. Hydrological Processes 25: 465-498.

Braat, L. C. (2018). Five reasons why the science publication "assessing nature's contributions to people" (Diaz et al. 2018) would not have been accepted in ecosystem services. Ecosystem Services 30: A1A2.

Burkhard, B., Petrosillo, I., and Costanza, R. (2010). Ecosystem services - bridging ecology, economy and social sciences. Ecological Complexity 7: 257-259.

Byg, A., Novo, P., Dinato, M., Moges, A., Tefera, T., Balana, B., Woldeamanuel, T., and Back, H. (2017). Trees, soils and warthlogs - Distribution of services and disservcies from reforestation areas in southern Ethiopia. Forest Policy and Economics 84: 112-119.
Caballero-Serrano, V., Alday, J. G., Amigo, J., Caballero, D., Carrasco, J. C., McLaren, B., and Onaindia, M. (2017). Social perceptions of biodiversity and ecosystem services in the Ecuadorian Amazon. Human Ecology 45: 475-486.

Cáceres, D. M., Tapella, E., Quétier, F., and Díaz, S. (2015). The social value of biodiversity and ecosystem services from the perspectives of different social actors. Ecology and Society 20(1): 62.

Carson, S., Kentatchime, F., Nana, E. D., Cole, B. L., and Godwin, H. (2018). Visions from local populations for livelihood-based solutions to promote forest conservation sustainability in the Congo Basin. Human Ecology 46: 887-896.

Chan, K. M. A., Satterfield, T., and Goldstein, J. (2012). Rethinking ecosystem services to better address and navigate cultural values. Ecological Economics 74: 8-18.

Comberti, C., Thornton, T. F., de Echeverria, V. W., and Patterson, T. (2015). Ecosystem services or services to ecosystems? Valuing cultivation and reciprocal relationships between humans and ecosystems. Global Environmental Change 34: 247-262.

Costanza, R., dArge, R., de Groot, R., Farber, S., Grasso, M., Hannon, B., Limburg, K., Naeem, S., Oneill, R. V., Paruelo, J., Raskin, R. G., Sutton, P., and van den Belt, M. (1997). The value of the world's ecosystem services and natural capital. Nature 387: 253-260.

Costanza, R., de Groot, R., Braat, L., Kubiszewski, I., Fioramonti, L., Sutton, P., Farber, S., and Grasso, M. (2017). Twenty years of ecosystem services: How far have we come and how far do we still need to go? Ecosystem Services 28: 1-16.

Cundill, G., Bezerra, J. C., De Vos, A., and Ntingana, N. (2017). Beyond benefit sharing: Place attachment and the importance of access to protected areas for surrounding communities. Ecosystem Services 28: $140-148$.

Cuni-Sanchez, A., Pfeifer, M., Marchant, R., and Burgess, N. D. (2016). Ethnic and locational differences in ecosystem service values: Insights from the communities in forest islands in the desert. Ecosystem Services 19: 42-50.

Cumming, G. S., and Maciejewski, K. (2017). Reconciling community ecology and ecosystem services: Cultural services and benefits from birds in south African National Parks. Ecosystem Services 28: 219 227.

Díaz, S., Demissew, S., Carabias, J., Joly, C., Lonsdale, M., Ash, N., et al (2015). The IPBES conceptual framework - Connecting nature and people. Current Opinion in Environmental Sustainability 14: 1-16.

Díaz, S., Pascual, U., Stenseke, M., Martin-Lopez, B., Watson, R., Molnar, Z., Hill, R., et al (2018). Assessing nature's contributions to people. Science 359(6373).

Dawson, N., and Martin, A. (2015). Assessing the contribution of ecosystem services to human wellbeing: A disaggregated study in western Rwanda. Ecological Economics 117: 62-72.

Dave, R., Tompkins, E. L., and Schreckenberg, K. (2017). Forest ecosystem services derived by smallholder farmers in North-Western Madagascar: Storm hazard mitigation and participation in forest management. Forest Policy and Economics 84: 72-82.

De Groot, R. S., Wilson, M. A., and Bouman, R. M. J. (2002). A typology for the classification, description and valuation of ecosystem services, goods and services. Ecological Economics 41: 393-408.

Delbanco, A., Burgess, N. D., and Cuni-Sanchez, A. (2017). Medicinal plant trade in northern Kenya: Importance, uses and origin. Economic Botany 71: 13-31.

Doumenge, C. (1998). Forest diversity, distribution, and dynamique in the Itombwe Mountains, south-Kivu, Congo Democratic Republic. Mountain Research and Development 18: 249-264.

Durand, L. (2005). Los mitos y la conservación ambiental. Revista Líder 13: 215-226.

Fa, J. E., Currie, D., Meeuwig, J., (2003). Bushmeat and food security in the Congo Basin: Linkages between wildlife and people's future. Environmental Conservation 30: 71-78. 
Farber, S. C., Costanza, R., and Wilson, M. A. (2002). Economic and ecological concepts for valuing ES. Ecological Economics 41: 375392.

Fischer, E. (1996). Die Vegetation Des Parc National De Kahuzi-Biega, Sud-Kivu, Zaire, Erdwissenschaftliche Forschung.

Fisher, B., Turner, R. K., and Morling, P. (2009). Defining and classifying ecosystem services for decision making. Ecological Economics 68: 643-653.

Gauthier, M., and Pravettoni, R. (2017). Reserved! An Atlas on indigenous peoples facing nature conservation. Published online at http:// journalismgrants.org/projects/reserved. Accessed Mar 2019

Golden, C. D., Fernald, L. C., Brashares, J. S., Rasolofoniaina, B., and Kremen, C. (2011). Benefits of wildlife consumption to child nutrition in a biodiversity hotspot. PNAS 108: 19653-19656.

Gould, R. K., Ardoin, N. M., Woodside, Y., Satterfield, T., Hannahs, N., and Daily, C. G. (2014). The forest has a story: Cultural ecosystem services in Kona, Hawai'i. Ecology and Society 19: 55.

Guerbois, C., and Fritz, H. (2017). Patterns and perceived sustainability of provisioning ecosystem services on the edge of a protected area in times of crisis. Ecosystem Services 28: 196-206.

Gillison, G. (1980). Images of nature in Gimi thought. In MacCormack, C., and Strathern, M. (eds.), Nature, culture and gender, Cambridge Univ. Press., Cambridge, pp. 143-173.

Hartter, J., and Goldman, A. (2011). Local responses to a forest park in western Uganda: Alternate narratives on fortress conservation. Oryx 45: 60-68.

Howe, C., Suich, H., Vira, B., and Mace, G. M. (2014). Creating winwins from trade-offs? Ecosystem services for human well-being: A meta-analysis of ecosystem service trade-offs and synergies in the real world. Global Environmental Change 28: 263-275.

Imani, G., Zapfack, L., Kalume, J., Riera, B., Cirimwami, L., and Boyemba, F. (2016). Woody vegetation groups and diversity along the altitudinal gradient in mountain forest: Case study of KahuziBiega National Park and its surroundings, RD Congo. Journal of Biodiversity and Environmental Sciences 8: 134-150.

Iniesta-Arandia, I., García-Llorente, M., Aguilera, P. A., Montes, C., and Martín-López, B. (2014). Socio-cultural valuation of ecosystem services: Uncovering the links between values, drivers of change and human well-being. Ecosystem Services 108: 36-48.

Kari, S., and Korhonen-Kurki, K. (2013). Framing local outcomes of biodiversity conservation through ecosystem services: A case study from Ranomafana, Madagascar. Ecosystem Services 3: 32-39.

Kasangaki, A., Kanyamibwa, S., Burgess, N., et al (2012). Capturing the benefits of ecosystem services to guide decision-making in the Greater Virungas Landscape of the Albertine Rift Region. ARCOS, University of Cambridge and WWF-US. Project Technical Report to MacArthur Foundation.

Kovács, E., Kelemen, E., Kaloczkai, A., Margoczi, K., Pataki, G., Gebert, J., Malovics, G., Balazs, B., Roboz, A., Kovacs, E. K., and Mihok, B. (2015). Understanding the links between ecosystem service trade-offs and conflicts in protected areas. Ecosystem Services 12: $117-127$.

Kujirakwinja, D., Plumptre, A. J., Twendilonge, A., Mitamba, G., Mulamba, L., Wasso, J. D. D., et al (2018). Establishing the Itombwe natural reserve: Science, participatory consultations and zoning. Oryx. https://doi.org/10.1017/S0030605317001478.

Lakerveld, R. P., Lele, S., Crane, T. A., Fortuin, K. P. J., and SpringateBaginski, O. (2015). The social distribution of provisioning ecosystem services: Evidence and insights from Odisha, India. Ecosystem Services 14: 56-66.

Lewan, L., and Söderqvist, T. (2002). Knowledge and recognition of ecosystem services among the general public in a drainage basin in Scania, southern Sweden. Ecological Economics 42: 459-467.

Lamarque, P., Tappeiner, U., Turner, C., Steinbacher, M., Bardgett, R. D., Szukics, U., and Lavorel, S. (2011). Stakeholder perceptions of grassland ecosystem services in relation to knowledge on soil fertility and biodiversity. Regional Environmental Change 11: 791-804.

Martín-López, B., Iniesta-Arandia, I., García-Llorente, M., Palomo, I., Casado-Arzuaga, I., Del Amo, D. G., et al (2012). Uncovering ecosystem service bundles through social preferences. PLoS One 7(6): e38970.

Martin, A., Akol, A., and Gross-Camp, N. (2015). Towards an explicit justice framing of the social impacts of conservation. Conservation \& Society 13: 166-178.

Martin, A., Coolsaet, B., Corbera, E., Dawson, N. M., Fraser, J. A., Lehmann, I., and Rodriguez, I. (2016). Justice and conservation: The need to incorporate recognition. Biological Conservation 197: 254-261.

Milcu, A. I., Hanspach, J., Abson, D., and Fischer, J. (2013). Cultural ecosystem services: A literature review and prospects for future research. Ecology and Society 18: 44.

Millennium Ecosystem Assessment (2005). Millennium ecosystem assessment. Ecosystems and human well-being : Synthesis, Island Press, Washington, DC.

Mokoso, J. M., Kavatsurwa, S. M., Birhashirwa, R. N., and Habimana, H. N. (2015). Utilisation des resources forestieres ligneuses par la population habitant de la zone submontagnarde du parc National de Kahuzi-Biega (RD Congo). International Journal of Innovation and Applied Studies 11: 508-521.

Mokoso, J. M., van Diggelen, R., Mwanga, J. C. M., Ntahobavuka, H., Malaisse, F., Robbrecht E. (2012) Enthnobotanic survey of Pteridophytes, assessment of extinction risk and conservation strategies in the surroundings of the Kahuzi Biega National Park (DR Congo). Geo-Eco-Trop 36: 137-158.

Mutoko, M., Hrin, L., and Shisanya, C. A. (2015). Tropical forest conservation versus conversion trade-offs: Insights from analysis of ecosystem services provided by Kakamega rainforest in Kenya. Ecosystem Services 14: 1-11.

Muvundja, F. A., Uwikunda, S. H., Mande, P., Alunga, L. G., Balagizi, K. I., and Isumbisho, M. P. (2013). Valorisation de la chenille comestible Bunaeopsis aurantiaca dans la gestion communautaire des forêts du Sud-Kivu (République Démocratique du Congo). VertigO. https://doi.org/10.4000/vertigo.13929.

Myers, N., Mittermeier, RA., Mittermeier, CG., Fonseca GAB., Kent, J., (2000). Biodiversity hotspots for conservation priorities. Nature. 403: 853 \pm 858 . https://doi.org/10.1038/35002501PMID:10706275.

Nangalire, N. O., Mushagalusa, M. M., and Ntamwira, N. S. (2017). Contribution of the abundance study and diversity of woody species of the mountain forest of Burhinyi, east of the Democratic Republic of Congo. Geo-Eco-Trop 41: 1-12.

National Geographic (2017). Why Pygmies Are Dealing Weed to Survive. Available at: https://www.nationalgeographic.com/news/ 2017/03/democratic-republic-congo-pygmy-grow-deal-weed/. Accessed Mar 2019

Olivero, J., Fa, J. E., Farfán, M. A., Lewis, J., Hewlett, B., Breuer, T., et al (2016). Distribution and numbers of pygmies in Central African forests. PLoS ONE 11: e0144499.

Omari, I., Hart, J. A., Butynski, T. M., Birhashirwa, N. R., Upoki, A., M'Keyo, Y., et al (1999). The Itombwe massif, Democratic Republic of Congo: Biological surveys and conservation, with an emphasis on Grauer's gorilla and birds endemic to the Albertine rift. Oryx 33: 301-322.

Orenstein, D. E., and Groner, E. (2014). In the eye of the stakeholder: Changes in perceptions of ecosystem services across an international border. Ecosystem Services 8: 185-196.

Paudyal, K., Baral, H., and Keenan, R. J. (2018). Assessing social values of ecosystem services in the Phewa Lake watershed, Nepal. Forest Policy and Economics 90: 67-81.

Plumptre, A.J., Behangana, M., Davenport, T.R.B., Kahindo, C., Kityo, R., Ndomba, E., Nkuutu, D., Owiunji, I., Ssegawa, P., and Eilu, G. (2003). The Biodiversity of the Albertine Rift. Albertine Rift 
Technical Reports No. 3, p. 105. Available at: www.albertinerift. orgnarift-publications. Accessed Mar 2019

Plumptre, A.J., Conservation, W., Kujirakwinja, D., and Conservation, W. (2009). Conservation of landscapes in the Albertine Rift. In Protected Areas, Governance and Scale. USA.

Raymond, C. M., Brown, G., and Weber, D. (2010). The measurement of place attachment: Personal, community and environmental connections. Journal of Environmental Psychology 30: 422-434.

Raymond, C. M., Singh, G. G., Benessaiah, K., Bernhardt, J. R., Levine, J., Nelson, H., Turner, N. J., Norton, B., Tam, J., and Chan, K. M. A. (2013). Ecosystem services and beyond: Using multiple metaphors to understand human-environment relationships. Bioscience 63: $536-546$.

Rickenbach, O., Reyes-García, V., Moser, G., and García, C. (2017). What explains wildlife value orientations? A study among Central African Forest dwellers. Human Ecology 45: 293-306.

Rodriguez, J. P., Beard, T. D. Jr., Bennett, E. M., Cumming, G. S., Cork, S. J., Agard, J., Dobson, A. P., and Peterson, G. D. (2006). Tradeoffs across space, time, and ecosystem services. Ecology and Society $11: 28$.

Russell, R., Guerry, A. D., Balvanera, P., Gould, R. K., Basurto, X., Chan, K. M. A., Klain, S., Levine, J., and Tam, J. (2013). Humans and nature: How knowing and experiencing nature affect well-being. Annual Review of Environment and Resources 38: 473-502.

Scholte, S. S. K., Teeffelen, A. J. A., and Verburg (2015). Integrating socio-cultural perspectives into ecosystem service valuation: A review of concepts and methods. Ecological Economics 114: 67-78.

Shalukoma, C., Duez, P., Bigirimana, J., Bogaert, J., Stevigny, C., Pongombo, C., and Visser, M. (2016). Characterization of traditional healers in the mountain forest region of Kahuzi-Biega, south-Kivu, DR Congo. Biotechnology, Agronomy, Society and Environment 20: $25-41$.

Siren, A., and Machoa, J. (2008). Fish, wildlife, and human nutrition in tropical forests: A fat gap? Interciencia 33: 186-193.

Smit, I. P. J., Roux, D. J., Swemmer, L. K., Boshoff, N., and Novellie, P. (2017). Protected areas as outdoor classrooms and global laboratories: Intellectual ecosystem services flowing to-and-from a National Park. Ecosystem Services 28: 238-250.

Smith, M. K. S., Roux, D. J., and Hayes, J. (2017). Adventure racing enables access to cultural ecosystem services at multiple scales. Ecosystem Services 28: 148-161.

Sop, T. K., Oldeland, J., Bognounou, F., Schmiedel, U., and Thiombiano, A. (2012). Ethnobotanical knowledge and valuation of woody plants species: A comparative analysis of three ethnic groups from the sub-
Sahel of Burkina Faso. Environment, Development and Sustainability 14: 627-649.

Spira, C., Kirkby, A., Kujirakwinja, D., and Plumptre, A. J. (2017). The socio-economics of artisanal mining and bushmeat hunting around protected areas: Kahuzi- Biega National Park and Itombwe nature reserve, eastern Democratic Republic of Congo. Oryx. https://doi. org/10.1017/S003060531600171X.

Steinhauser-Burkart, B., Mühlenberg, M., and Slowik, J. (1995). KahuziBiega National Park. IZCN/GTZ-Project 'Integrated Nature Conservation in East Zaire'. Park brochure.

Sullivan, S. (2013). Banking nature? The spectacular financialisation of environmental conservation. Antipode 45: 198-217.

Tadesse, G., Zavaleta, E., Shennan, and Fitzsimmons, M. (2014). Local ecosystem service use and assessment vary with socio-ecological conditions: A case of native coffee-forests in southwestern Ethiopia. Human Ecology 42: 873-883.

Tata Ngome, P. I., Shackleton, C., Degrande, A., and Tieguhong, J. C. (2017). Addressing constraints in promoting wild edible plants' utilization in household nutrition: Case of the Congo Basin Forest area. Agriculture \& Food Security 6: 20.

Van Vliet, N., Nebesse, C., and Nasi, R. (2015). Bushmeat consumption among rural and urban children from province Orientale, Democratic Republic of Congo. Oryx 49: 165-174.

Verdu, P. (2016). African pygmies. Current Biology 26: R1-R21.

Ward, C., Stringer, L., and Holmes, G. (2018). Changing governance, changing inequalities: Protected area co-management and access to forest ecosystem service: A Madagascar case study. Ecosystem Services 30: 137-148.

Willemen, L., Drakou, E. G., Dunbar, M. B., Mayaux, P., and Egoh, B. N. (2013). Safeguarding ecosystem services and livelihoods: Understanding the impact of conservation strategies on benefit flows to society. Ecosystem Services 4: 95-103.

Williams, D. R., Patterson, M. E., Roggenbuck, J. W., and Watson, A. E. (1992). Beyond the commodity metaphor: Examining emotional and symbolic attachment to place. Leisure Science 14: 29-46.

Wilson, E. O. (1984). Biophilia, Harvard University Press, Cambridge ISBN 0-674-07442-4.

Yumoto, T., Yamagiwa, J., Mwanza, N., and Maruhashi, T. (1994). List of plant species identified in Kahuzi-Biega National Park, Zaire. Tropics 3: 295-308.

Publisher's Note Springer Nature remains neutral with regard to jurisdictional claims in published maps and institutional affiliations. 